\begin{tabular}{ccccc}
$\mathbf{A}$ & $\mathbf{T}$ & $\mathbf{C}$ & $\mathbf{E}$ & $\mathbf{S}$ \\
\hline & \\
ROCZNIKI TEOLOGICZNE \\
Volume 65, issue 8 - 2018 \\
E n g 1 i h h v e r s i o n \\
DOI: http://dx.doi.org/10.18290/rt.2018.65.8-1en
\end{tabular}

REV. ZBIGNIEW GŁOWACKI

\title{
EUCHARISTIC SPIRITUALITY
}

\begin{abstract}
Appreciating the meaning of the liturgy in the overall activity of the Church consequently leads to the discovery of its relationship with Christian spirituality. This has resulted in the emergence of a field of theology called liturgical spirituality, in which the liturgy of the Church determines the quality of life of the believer and at the same time shapes it. Considering the importance and role of the Eucharist in a Christian's life, the fullest realization of liturgical spirituality is a believer's participation in the Eucharistic liturgy. Hence, we can talk about a socalled Eucharistic spirituality, which is an example of liturgical spirituality. The issue discussed in this article is summarized in the following question: how does the Eucharist shape the Christian life of a believer participating in it?
\end{abstract}

Keywords: Eucharist; spirituality; Christian life; worship.

\section{INTRODUCTION}

Louis Bouyer, in describing man's spirituality, mentions three levels of the spiritual development of human life. The first is one's inner life itself, which is essentially life experienced by man in an autonomous and conscious way. The second level is the spiritual life, which is one's inner life, formed on the basis of a concrete spiritual reality. The third level is one's religious life, in which the spiritual element that affects the whole of human life is God. ${ }^{1}$ This distinction makes it possible to grasp the essence of Christianity. Speaking very generally, this means consciously living one's religious life, for which the first and most important determinant is man's relationship

Rev. Dr. ZBigniew GŁowacki, John Paul II Catholic University of Lublin, Institute of Liturgy and Homiletics; address for correspondence: ul. Koncertowa 15, 20-866 Lublin; e-mail: zbigniew.glowacki@kul.pl

${ }^{1}$ Cf. Louis BOUYER, Wprowadzeniedo życia duchowego. Zarys teologii ascetycznej i mistycz$n e j$, transl. L. Rutowska (Warsaw: Instytut Wydawniczy PAX, 2014), 9-11. 
with God through Christ. In a Christian's life, the above relationship defines the whole of human existence, affecting every area of their life.

Therefore, Christian spirituality involves every religious activity whose aim is to establish a relationship with God so as to sustain and strengthen it. In the Catholic faith, as the French theologian points out, the spiritual life has its specificity. It is expressed in the conviction that God not only revealed himself to man throughout history by his words and works, and ultimately in the person of Christ, but that he is also present and active in our times through Christ who is present in the Church. ${ }^{2}$ The fullest form of the presence and action of Christ is the liturgy, which is "a sacred action surpassing all others; no other action of the Church can equal its efficacy by the same title and to the same degree" (SC 7).

Appreciating the importance of the liturgy in the Church's overall activity consistently leads to discovering its relationship with Christian spirituality. This resulted in the field of theology called liturgical spirituality, in which the liturgy of the Church determines the quality of the life of a believer and at the same time shapes it. Considering the importance and role of the Eucharist in a Christian's life, the fullest realization of liturgical spirituality is a believer's participation in the Eucharistic liturgy. Hence, we can talk about the so-called Eucharistic spirituality, which is an example of liturgical spirituality. ${ }^{3}$ The issue in this article is summarized in the following question: how does a believer's participation in the Eucharist form their Christian life?

\section{THE EUCHARIST DIRECTED TOWARDS HUMAN LIFE (THE RELATIONSHIP BETWEEN THE EUCHARIST AND LIFE)}

Eucharistic spirituality is the basic form of liturgical spirituality in the life of a believer. It is governed by the same principles that apply to the spirituality shaped by the entire liturgy. Burkhard Neunhauser defines the goal of liturgical spirituality as conforming to Christ by building a consciously lived Christian life through authentic participation in the liturgy. ${ }^{4}$ In this con-

\footnotetext{
${ }^{2}$ Cf. ibidem, 20.

${ }^{3}$ Cf. Andrzej SAntorski, "Eucharystia. III: Duchowość," in Leksykon duchowości katolickiej, ed. Marek Chmielewski (Lublin-Kraków: Wydawnictwo „M,” 2002), 251-252.

${ }^{4}$ Cf. Stanisław CzERwiK, "Duchowość liturgiczna i eucharystyczna - tajemnica wiary w liturgii i w życiu chrześcijańskim: Chrystus pośród nas (Kol 1, 27)," in Wiara liturgia ewangelizacja, ed. Samuela Klimas, Katarzyna Walkowiak (Kielce: „Jedność,” 2013), 27-28.
} 
text, the goal of liturgical spirituality is to change a believer's life. It involves shaping a person's life according to God's will, expressed in the liturgy and with the help of the means that the liturgy provides. Spirituality conceived as such clearly shows that one of its fundamental assumptions is to connect the liturgy with a Christian's life.

In this case, the liturgy is not only a celebration, isolated from the daily existences of the faithful, but has an influence on them, and what is more, it is one's primary determinant. Observing this fundamental relationship of Christian spirituality between the liturgy and a person's life relies on the definition of liturgy. If it is really to become the true source of a faithful person's life, it must be seen broadly as Christ's Mystery united in a specific celebration with the life of the participants of the liturgy. Liturgy according to this approach is not limited to the celebration itself, but goes beyond it, becoming a life liturgy. In the same way, the sacrament of the Eucharist should be perceived in the liturgy.

The entire spirituality formed by the liturgy has a unique place and fulfills a special role. Although the basis of Eucharistic spirituality, just like liturgical spirituality, is directing the Eucharist to transform man's life, its influence on a Christian's life is much greater than in the other sacraments. The uniqueness of the Eucharist in relation to the other sacraments concerns two realities. The first is Christ's presence and action in them. In each sacrament, Christ is really and truly present and working, but only the Eucharist is a sacrament where this presence is substantial, combined with the presence of the entire Mysterium Christi. The second sacramental reality is man's participation in Christ's Mystery. The Eucharist is the only sacrament in which a person is fully active in the Savior's life because it affects every dimension of a person's life with its effects. As John Paul II writes: "In this sacrament of bread and wine, food and drink, everything that is human is subjected to a special transformation and exaltation." 5 The celebration of other sacraments, both in the dimension of the presence of the Mystery of Christ, his actions and effects in the lives of believers, is aspectual. ${ }^{6}$

Such a total orientation of the Eucharist towards the life of believers in liturgical practice appears in two basic Eucharistic goals, namely sanctification and cult. The Eucharist, being the presence and actualization of Christ's

\footnotetext{
${ }^{5}$ John Paul II, Dominicae cenae, Rome 1980, no. 7.

${ }^{6}$ Cf. Bogusław Migut, "Duchowość eucharystyczna jako duchowość komunii," Roczniki Liturgiczno-Homiletyczne 3 (59) (2012): 84; cf. Czesław BARTNIK, Dogmatyka katolicka, vol. II (Lublin: Wydawnictwo KUL, 2012), 632-633.
} 
salvific sacrifice, is worship offered to the Father through Christ and at the same time it sanctifies man. Christ's latreutic and soteric action is combined in the Eucharist with the action of the Church, which includes each of the believers. A participant in the Eucharist is transformed through the sanctification he experiences in it, becoming a worshipper of God in spirit and truth. Taking into account the nature of man's participation in the Bloodless Sacrifice of Christ, the Eucharist cannot, therefore, be understood unilaterally, as is often the case, exclusively as worship to God offered him by Christ and man and as being associated with his sanctification. Without negating the priority of Christ's action in the Eucharistic and worshipping God as its main goal, it must be said that its goal is also man who participates in it and his personal transformation. Going further, we can say that Christ's worshipping the Father in the Eucharist is not separated from its participants, but directed towards man's total inclusion in it.

The purpose of a celebrated Eucharist cannot, therefore, simply be making present the sacrifice of Christ for its own sake, but it must be seen in the existential context of the Christian life. As a salvific sacrifice, it is fulfilled in the lives of the faithful when it leads its participants to take on Christ's attitude, becoming the source of the newness of life. Similarly, a person's transformation through participating in the Eucharist cannot be separated from worshipping God as its main goal. This existential aspect of the sacrifice offered on the altar does not diminish either the holiness of the Eucharist or Christ's action in it. In the end, Christ is always the primary entity of this cult. This cult is combined with man worshipping God in the celebration and furthermore unites with the one who, thanks to the Eucharist, become the life of believers. The Eucharistic cult cannot be understood as worship of God exceeding infinite creation, thus being inaccessible to man. It is essentially the cult of "a loving, redeeming transformation of the world in man's heart." The nature of the sanctifying cult of the Eucharist clearly shows that the basis of Eucharistic spirituality is this sacrament incorporating a man's entire life, meaning the cult man offers to God during the celebration, but also to the one thanks to whom participation in the Eucharist also becomes all of human existence.

\footnotetext{
${ }^{7}$ John PaUl II, Dominicae cenae, no. 7.
} 


\section{CHRIST'S SACRIFICE THE BASIS \\ OF EUCHARISTIC SPIRITUALITY}

The relationship between the Eucharist and the Christian life, which forms the basis of the Eucharistic spirituality and the present in it fundamental principle of the faithful's participation in the celebration of the Mass is a direct result of the very essence of the Eucharist as being Christ's sacrifice. It reveals to men the nature of God's life in the Holy Trinity. As Benedict XVI writes: "The first element of Eucharistic faith is the mystery of God himself, Trinitarian love." ${ }^{\prime}$ It is a sacrifice offered by the Son to the Father, and its content is his perfect obedience. It was received with love by the Father, and its sign is the gift of new life offered to the Son in the resurrection. ${ }^{9}$

At the same time, Christ's sacrifice offered on the altar, identical to the sacrifice of the cross, is an act of redemptive love that brings man salvation. The essence of Christ's sacrifice, therefore, is the reality of a double gift: first it is the gift of Christ for the Father, and then it is the gift which God gave to man in Christ. This gift in the second meaning cannot be limited to any one particular grace associated with the sacrifice of the Savior, since it is Christ himself, who, by giving himself up as a man, shows the love of God in his sacrifice. Therefore, the sacrificial act is an act by which God gives the entire life of his Son to man. ${ }^{10}$

Joseph Ratzinger, describing the Eucharistic sacrifice in the context of a blood sacrifice, unites the gift contained in it with a series of transformations that occurred both during the Last Supper and the passion and death of Christ associated with it. This happens every time in the celebration of the Eucharist, because for him, the Eucharist is "the sacrament of transformation." 11 The most important transformation that occurs during the celebration of the Eucharist at the moment of consecrating is the transformation of the earthly gifts of bread and wine into the Body and Blood of Christ. Thanks to this, the gifts offered by man, the fruit of his efforts and work, make Christ present on the altar, including his life and sacrifice, and these become

\footnotetext{
${ }^{8}$ Sacramentum Caritatis, no. 7.

${ }^{9}$ Cf. John Paul II, Ecclesia de Eucharistia, no. 13.

10 "In the Eucharist Jesus does not give us a 'thing,' but himself; he offers his own body and pours out his own blood. He thus gives us the totality of his life and reveals the ultimate origin of this love." Sacramentum Caritatis, no. 7.

${ }^{11}$ Joseph RATZINGER, "Świętowanie Eucharystii-źródło i szczyt życia chrześcijańskiego,” in IBIDEM, Opera Omnia, vol. XI: Teologia liturgii, ed. Krzysztof Góźdź, Marzena Górecka (Lublin: Wydawnictwo KUL, 2012), 413.
} 
his gift to the Father, accepted by him and also as a gift for man. ${ }^{12}$ The goal of consecration is significant here, meaning the transubstantiation of bread and wine. The presence of Christ and his saving work includes God's call to all participants of the Eucharist to participate in the life of Christ, and this is a call for man to be transformed. As J. Ratzinger writes: "The transformed bread and the transformed wine, in which the Lord gives himself as the lifegiving Spirit, aim to transform us so that we may become one bread with him and then one body with him.",13

According to J. Ratzinger, the transformation that is present in the Eucharistic consecration, although it is the central moment of the Eucharist, is not its final moment; on the contrary, it is the beginning of this transformation that takes place in the life of believers. This truth is expressed by the very structure of the Holy Mass, where consecration does not end the celebration, but is aimed at being in communion. It only fully expresses and fulfills the desire to be united with Christ, to be one with him: "The goal of the Eucharist is to transform people who receive it in aesthetic communio with his transformation." 14

Understanding the Eucharist as a sacrifice containing the transformation of earthly gifts into the Gift of Christ aimed at transforming man is an important issue in defining Eucharistic spirituality. Most important is the relationship that enters in between the Eucharistic sacrifice of Christ and its purpose, which is the transformation of the Christian life by its uniting with the life of Christ. This goal belongs to the essence of the Eucharist and does not constitute an external element in relation to it. The conversion of the life of believers cannot, therefore, be treated in the Eucharist only as its additional element, on the principle of a commitment arising from it, for example, a legal order. Since the Sacrifice of Christ is contained in the Eucharist, it is treated as a gift of God's love, accompanied by the obligation for its participants to change their lives, which should be treated as a response of love from the human side. The love of God, which is the soul of this sacrament, is to also be the deepest and first motive for changing a person's life, which is the personalistic character of Eucharistic spirituality. In fact, it is

\footnotetext{
12 "The Church has received the Eucharist from Christ her Lord not as one gift-however precious - among so many others, but as the gift par excellence, for it is the gift of himself, of his person in his sacred humanity, as well as the gift of his saving work." JOHN PAUL II, Ecclesia de Eucharistia, no. 11.

${ }^{13}$ RATZINGER, Świętowanie Eucharystii, 415.

${ }^{14}$ Ibidem.
} 
not simply a person forming specific human qualities and perfections by means of participating in the Eucharist, or treating it as a tool for Christian formation.

The essence of Eucharistic spirituality is a dialogue between God and man, in which the Eucharist from the human side is the experience of God's love and the existential response of a believer to God. Hence, the Holy Mass itself cannot be treated in liturgical spirituality as a formation tool. It should be noted that it is often treated as a form of a specific liturgical catechesis, whose goal is mainly to teach the faithful about the truths of the faith and the principles of morality, or as a meeting that allows the Church to experience communion. This approach to the Eucharist should not only be seen as a serious limitation, but above all as its instrumental treatment. In Eucharistic spirituality, it can be said that the Eucharist performs a formative function, but attention should be paid to the character of this formation. It takes place not so much on the basis of presenting specific principles, which ought to be implemented independently of the Eucharist, but on the basis of participation by entering into the sacrifice of Christ, leading to an ever deeper communion with him. Only then does this unity become the source of the life attitudes of believers in Eucharistic spirituality.

\section{REASONABLE SERVICE TO GOD AS THE PRINCIPLE OF EUCHARISTIC SPIRITUALITY}

The novelty of the cult offered to the Father by Christ consists in replacing all the sacrifices of the Old Covenant with one perfect sacrifice made by the Son of God. Christ, by offering himself to the Father and concluding this sacrifice at the Last Supper in the Eucharist rite, also united these with the sacrifice offered in it by the Church. Its matter is no longer animals sacrificed in the temple, but man himself who gives his life to God as a gift. St. Paul expressed the essence of such a sacrifice in the Letter to the Romans in a request directed to the brothers to offer their bodies as a sacrifice, a sign of their "reasonable service to God" ( 12,1-2). Benedict XVI sees in these words "the image of a new cult, the total sacrifice made of one's own person in communion with the whole Church." 15 This concept of a "spiritual sacrifice" in Eucharistic spirituality

\footnotetext{
${ }^{15}$ BenedICt XVI, Sacramentum Caritatis, no. 70.
} 
becomes the basic principle forming a person's life in the likeness of Christ's life.

An important question for Christian spirituality formed by the Eucharist is how man's participation in Christ's sacrifice in the form of $\lambda o \gamma \iota \kappa \grave{\eta} \lambda \alpha \tau \rho \varepsilon i \alpha$ transforms one's life. The sacrifice of the participants of the Eucharist is called a spiritual sacrifice, which clearly indicates the priority of a spiritual, internal element, which is prior to an act or a material element. Just as in Christ's sacrifice, so also one's free will is first offered to God in sacrifice when participating in the Eucharist. ${ }^{16}$ A man's transformation in the sacrifice of the altar, therefore, starts with offering his desires and intentions to God with an attitude of obedience to the will of God. At this point, it is worth paying attention to the integral character of this sacrifice emphasized by Pope Benedict. In fact, according to him, there is no such aspect or dimension of man's life that cannot be treated in the Eucharist as a matter for one's spiritual sacrifice. In this sense, this concerns man's entire existence. ${ }^{17}$

The beginning of the transformation of man's life in Eucharistic spirituality is a sacrifice made of one's will. In the concept of "reasonable" service, according to the teaching of Pope Benedict, we can also see man's acceptance of the Christian mentality. According to this Christian way of thinking, man accepts God's vision of the world and principles of behavior as God revealed them to him. The revival of human life in the Eucharistic spirituality, therefore, is based on a new way of thinking and evaluating, which in turn translates into concrete attitudes and choices adopted in life. It can be said that the first step in the transformation of man through the Eucharist is taking in the contents of Revelation, the acceptance of God's own truth as one's own. This process takes place in the celebration of the Eucharist by offering oneself, and the liturgy of the word, which reveals God's will to man, leads him directly to the sacrifice of the liturgy and consequently to the transformation of his thinking.

However, the spiritual sacrifice in the life of believers is not limited to the celebration of the Eucharist. Although it is a place for offering a sacrifice, its effects go beyond the limits of the celebration. Submitting one's will to God's will leads man not only to change his way of thinking, but ultimately to accept the attitudes shaped during the celebration in his everyday life. This practically means Christian perfection expressed in a concrete

\footnotetext{
${ }^{16}$ Cf. Bogusław Migut, "Eklezjotwórczy charakter Eucharystii jako ofiary," Seminare 23 (2006): 14-15.

${ }^{17}$ Cf. Benedict XVI, Sacramentum Caritatis, no. 71.
} 
mentality and related morality. For Eucharistic spirituality, the important issue is to connect morality with its sacramental source. In this spirituality, a human act is not simply judged as good or bad on the basis of the law given by God. Referring a deed to the Eucharist makes us see it as an act in which the believer honors God. Through concrete deeds, human life is perceived by men as a place of worship, and the specific criterion of good and evil becomes the glory of God in them. John Paul II describes Christian morality and the pursuit of holiness in this way, calling the lives of the saints in the Encyclical Veritatis splendor "an adoration of God and His infinite holiness" and attributes to the moral life of Christians "the value of reasonable service to God," which has its source in the sacraments and above all in the Eucharist. ${ }^{18}$ Eucharistic spirituality is therefore intended to lead the participants of the Eucharist to treat their whole lives as worshipping God.

\section{THE CHRISTIAN LIFE IS THE EUCHARISTIC LIFE}

Eucharistic spirituality, which means that the participants of the Eucharist are involved in the sacrifice of Christ and thus transform their lives into what is treated as the life of God's cult, has existential consequences. At this point, we should ask the question of how the Eucharist translates into this cult outside of the celebration, meaning performed in a Christian's everyday life. The answer to this comes from the Eucharist being treated as a gift of Christ for the Father and for man expressed in his sacrifice made present on the altar. In the letter Dominicae cenae, John Paul II writes about the context of the "sacramental lifestyle of a Christian,"19 and in Ecclesia de Eucharistia, he emphasizes that the Eucharist is an invaluable gift for man. Taking into account these two dimensions of the Eucharist, Eucharistic spirituality will consist in shaping an attitude of gratitude in man for the gift received in Christ, and then by treating the events of his life in a sacramental manner according to this model.

Treating the Eucharist as a gift implies the necessity of putting the Paschal Mystery of Christ in the first place in Eucharistic spirituality. The Eucharistic transformation of a believer's life has its source in it and this occurs precisely through it. This is not only about the celebration itself and

\footnotetext{
${ }^{18}$ Cf. John PaUl II, Veritatis splendor, no. 107.

${ }^{19}$ John PAUl II, Domini caecenae, no. 7.
} 
properly distributing the accents among someone being present in it, Christ's action and man's participation in it, or worship and sanctification. The participation of the faithful in the celebration of the Mass depends on previously focusing on the Mysterium Christi. Particularly important in this respect is to prepare for the celebration by directing one's attention during the Eucharist on the Word of God, individual prayer, practices of popular piety, as well as adoration of the Blessed Sacrament. As stated above, the condition for the transformation of a person's life in the Eucharist is its participants being aware of the magnitude of the gift that they have received from God through it. All liturgical and non-liturgical forms of worship aimed at directing believers to participate in the Eucharist allow them to discover the value of Christ's sacrifice, and as a consequence the participants of the celebration will enter into it and unite their lives with it. Eucharistic spirituality is, therefore, supposed to lead to a life lived according to the gift man receives in the Eucharist.

The sacramental lifestyle must first be seen as one's participation in the sacraments, with the Eucharist taking a central place in a Christian's life. Yet going further, in the Eucharist, we can see that we treat life in an analogous way to the celebrated Eucharist. Participation in it will lead man to experience his life as the place of God's revelation in Christ by perceiving his presence and action in concrete situations. Moreover, Eucharistic spirituality leads to taking on the attitude of sacrifice outside of the celebration. In the lives of the faithful, this will mean a kenosis following the example of Christ and ever more perfectly fulfilling the will of the Father and living for one's brothers. Its adoption in Christian life will make it God's cult and a place of sanctification. The best summary of this way of life, which has its source in the Eucharist, are the words of Benedict XVI: "Christianity's new worship includes and transfigures every aspect of life: 'Whether you eat or drink, or whatever you do, do all to the glory of God' (1 Cor 10:31)."20

This transformation of man, by being united with the sacrifice of Christ, is not limited to the individual dimension of one's life, and it is not exhausted by the anthropological dimension. The Eucharist, including the spirituality based on it, also has a social dimension, as Benedict writes: "The 'mysticism' of this sacrament has a social character." ${ }^{\text {21 }}$ This sacrament, being the sacrament of man's unity with Christ, leads to unity with all those

\footnotetext{
${ }^{20}$ Benedict XVI, Sacramentum Caritatis, no. 71.

${ }^{21}$ Ibidem, no. 89.
} 
who receive the gift of Christ. In this way, the Eucharist transforms not only an individual human being, but it also affects interpersonal relationships, communities and social systems. This process is not limited and it does not stop at any one point, but it incorporates the whole world around itself, becoming the Eucharistic transformation of all reality.

\section{CONCLUSION}

Eucharistic spirituality, which is an example of liturgical spirituality, is shaping the Christian life based on believers participating in the sacrament of the Eucharist. The foundation of spirituality understood as such is a person's life focused on their transformation. The sacrifice of Christ is the reason for the exemplary Eucharistic change that motivates the lives of the Mass participants. It is present in the Eucharist, it is a gift of God to believers, and at the same time it is an invitation to enter into it through the spiritual sacrifice of the faithful. Treated as doing the will of God, it results in forming the Christian mentality. This, in turn, translates into man accepting the specific attitudes presented in the Eucharist, where the main attitude is one of sacrifice. Eucharistic spirituality, where the celebration of the Eucharist is the central moment, translates onto the everyday life of the faithful. This transformation of an individual's life leads to the transformation of social relationships and, ultimately, the entire world.

\section{BIBLIOGRAPHY}

BARTNIK, Czesław. Dogmatyka katolicka [Catholic Dogmatics], vol. II. Lublin: Wydawnictwo KUL, 2012.

BENEDICT XVI. Apostolic Exhortation 'Sacramentum Caritatis.' Rome: Libreria Editrice Vaticana, 2007.

BOUYER, Louis. Wprowadzenie do życia duchowego. Zarys teologii ascetycznej i mistycznej [Introduction to Spiritual Life. An Outline of Ascetic and Mystical Theology]. Translated by Lucyna Rutowska. Warsaw: Instytut Wydawniczy PAX, 2014.

CZERwiK, Stanisław. "Duchowość liturgiczna i eucharystyczna-tajemnica wiary w liturgii i w życiu chrześcijańskim: Chrystus pośród nas (Kol 1,27).” In Wiara liturgia ewangelizacja [Liturgical and Eucharistic Spirituality. The Mystery of Faith and Liturgy in the Christian Life: Christ among Us (Col 1,27), in Faith Liturgy Evangelization], ed. Samuela Klimas, Katarzyna Walkowiak. Kielce: „Jedność,” 2013.

John Paul II. Apostolic Letter 'Dominicae cenae.' Rome: Libreria Editrice Vaticana, 1980. 
John Paul II. Encyclical 'Ecclesia de Eucharistia.' Rome: Libreria Editrice Vaticana, 2003.

John PaUl II. Encyclical 'Veritatis splendor.' Rome: Libreria Editrice Vaticana, 1993.

Migut, Bogusław. "Duchowość eucharystyczna jako duchowość komunii" [Eucharistic Spirituality as Communion Spirituality]. Roczniki Liturgiczno-Homiletyczne 3 (59) (2012): 81-90.

Migut, Bogusław. "Eklezjotwórczy charakter Eucharystii jako ofiary" [The Ecclesial Building Character of the Eucharist as a Sacrifice]. Seminare 23 (2006): 11-28.

RATZINGER, Joseph. "Świętowanie Eucharystii-źródło i szczyt życia chrześcijańskiego" [Celebrating the Eucharist, the Source and Summit of the Christian Life]. In IBIDEM. Opera Omnia, vol. XI: Teologia liturgii [Theology of the Liturgy], edited by Krzysztof Góźdź, Marzena Górecka. Lublin: Wydawnictwo KUL, 2012.

SANTORSKI, Andrzej. "Eucharystia. III. Duchowość." In Leksykon duchowości katolickiej [The Eucharist. III. Spirituality, in: Lexicon of Catholic Spirituality], ed. Marek Chmielewski. Lublin-Kraków: Wydawnictwo „M,” 2002.

Translated by Jan Kobytecki

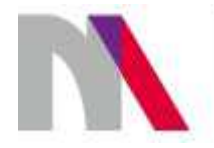

The preparation of the English version of Roczniki Teologiczne (Annals of Theology) and its publication in electronic databases was financed under contract no. 836/P-DUN/2018 from the resources of the Minister of Science and Higher Education for the popularization of science. 